\title{
MELCHIZEDEK THROUGH THE EYES OF THE AUTHOR OF THE EPISTLE TO THE HEBREWS
}

The article intends to study the person of Melchizedek as described in the Epistle of Hebrews. It provides an overview of sources who have engaged with this biblical hero and interpretations that exist on his personality. It has been shown that there are many varied opinions regarding Melchizedek. The article attempts yet again, following closely the author of the Epistle, to unravel the secret of this person. The research is based on the hermeneutic-exegetical method. It is shown how, step-by-step, the author of Hebrews guides the reader in the disclosure of the identity of Melchizedek, which undeniably has a serious impact on the thinking of his first and of contemporary readers. The article starts with a brief introduction to the Epistle followed by a description of the historical background of the first century. It is shown that the Epistle in a narrative style was written either during the period of persecution of Christians, or just preceding it. Apparently, difficult times affected the faith of the members of the community. Some of them had cooled off in their faith, some had departed from Christ, some had fallen into sin, some may have again returned to the Jewish system of values. In the Epistle, the author tries to draw the attention of community members again to Christ. He shows Christ's superiority over the prophets, the angels, over Abraham, Moses, and Aaron as well as over the Old Testament priestly system of temple service. The author demonstrates the divinity of Jesus Christ, talks about the purposelessness, meaninglessness and even the danger of life without $\mathrm{Him}$ and calls for a return to faith in Him. In his hermeneuticalexegetical study of the Old Testament narratives of Melchizedek in Genesis 14:18-20 and Ps.110:4, the author of the Epistle uses traditional rabbinic methods of interpretation of Scripture acceptable in his time. He shows that Melchizedek is not only a historical person, but also an eschatological one. He is not only a prototype of the priest of the future, not just a prototype of the Messiah. He actually is the Messiah, the Son of God. The person of Melchizedek was touched on by the author of the Epistle not only in order to show His divinity and identity with Christ, but also to show that God the Father acted through Him in the Old Testament and also continues to do so in the New Testament. Jesus is a faithful High Priest.

Keywords: Melchizedek; Melchizedek and Christ; Melchizedek in the Epistle to the Hebrews; The priesthood of Melchizedek; Christ the High Priest; Melchizedek and Abraham.

\section{Introduction}

At all times, Melchizedek was considered a mysterious and mystifying person for readers and Bible interpreters. Much research has been devoted to him and many very different opinions are held regarding him.

We find the first reference to him, which became the basis for the biblical and extra-biblical narratives of Melchizedek (Somov, 2009: 2), in the book of Genesis (14:1820). It speaks of a meeting between him and the patriarch Abraham, one of the main figures and respected authorities of the Israeli people. The second, very short reference is found in Psalm 109. Most scholars attribute the time of the Psalms writing to the monarchy period, in particular to the reign of King David, and connect the text to the coronation ceremonies in the Temple at Jerusalem, the celebration of the New Year or to festivities dedicated to victory in one of the battles (ibid, 2-3). The third story we find already in the New Testament - in Hebrews.

In extrabiblical literature, Melchizedek is mentioned in the Targumim, in Midrash, Talmud, in the Qumran manuscripts, in the Slavic book of Enoch, in the early Christian Coptic treatise Nag-Hammadi and others. Filo of Alexandria, Joseph Flavius also talk about Melchizedek.
What do the interpreters say about Melchizedek? Both, among Jews and among Christian interpreters, there is no consensus on the matter:

Some Jewish interpreters identify Melchizedek with Shem, who survived Abraham according to the Massorean chronology, for almost a century. In the Midrash on Genesis it says: "When Abram, returning home to the south, approached the outskirts of Jerusalem, one of the greatest people of that time came out to meet. It was Shem, the son of Noah, known by the name of Malki Zedek (Just King), who regularly offered sacrifices to Ashem and led a yeshiva in which they taught knowledge about the true G-d" (Rabbi Moshe Veysman). Why these Jews see Shem in Melchizedek is not known. Maybe this is due to the influence of the Targums and some rabbinical traditions in which Melchizedek is presented as a historical person, or maybe the blessing is transmitted from Noah to Shem (Gen. 9:26) and then from Shem to Abraham?

Others considers him an eschatological figure and a prototype of the great priest of the future century, while at the same time distinguishing him from the Messiah, who is mentioned in Ps. 110 (Bruce, 1964: 107; Somov, 2009: 9-10). 
Philo of Alexandria considered Melchizedek as the embodied Logos. According to Philo's concept, God, whom no one has seen, is revealed to the outside world through the Personality who is the "Original Son of God", "Man of God", "Co-ruler of God", etc. (Tantlevsky, 1994: 269).

Josephus Flavius describes Melchizedek as a purely historical figure, a Canaanite ruler, the first priest, the founder of Jerusalem and the first temple, who by virtue of his righteousness pleased God. "The king of Sodom went out to meet him to that place called the King Plain." Here Abram was received by the king of the city of Solima, Melchizedek. The name of the latter means "the righteous king," which everyone recognized him, so that for this reason he was also a servant of the Lord God. Salem was later called Jerusalem" (Flavius, v.1, ch. 10).

Among Christians, there are also several views regarding Melchizedek.

One of the views that Christian interpreters hold partially overlaps with the second Jewish perspective: according to it, Melchizedek is a prototype of the great High Priest. Here, however, Christians went a little further and also considered Melchizedek a prototype of Christ (Tolkovaya Bibliya, 458; Peeler, 2011: 163; Mathews, 2013: 120; loann Zlatoust; Feofilakt; Granerød; Somov; Slavyanskiy Bibleyskiy Kommentariy, 2016: 1774).

In the early Christian Gnostic Coptic treatise "Melchizedek", this Person, "dwelling in time in heaven, is directly identified with Jesus Christ, the Son of God." The treatise has Melchizedek speak these lines in first person: "... people. And [...] you beat me, [...] you throw me [...] a corpse. And you crucified me at the third hour, on the eve of Sunday, until the ninth hour. And after that I rose from the dead [...] came out of [...] into me [...] my eyes saw [...] they did not find anyone ..." (Apokrif Melkhisedek).

In the book of Slavic Enoch, Melchizedek is described as immaculately conceived from God by Sophonim, the wife of Nir, brother of Noah, born of her, taken to heaven by Angel Gabriel and embodied in all post-flood high priests, including the High Priest of the end of days. "And it happened when the lad stayed forty days in the house of Nir, the Lord said to the archangel Gabriel: "Go down to the land to Nir the priest, and take the lad Melchizedek, and place him in Paradise of Eden for preservation. For the time is already near, (when) l'll put (all) water on the earth, and all that exists on earth will perish. And we will create a different kind, and Melchizedek will be the head of the priests in that kind"" (Kniga Slavyanskogo Yenokha).

According to another version, and this view was held by members of one of the Qumran sects (Tantlevsky, 1994: 278) which also some modern scholars adhere to (Kharchlaa, 1990: 507), Melchizedek, taking into account v. 7:1-11 and especially $7: 3$, could be an angel. In this case, perhaps the author of the book of Hebrews wanted to show the superiority of Christ over Melchizedek, as well as the fact that "the Son of God is the High Priest in that line," to which Melchizedek belongs as just a priest."

In the Qumran manuscript "Songs of the Sabbath burnt offering, or the Angelic Liturgy," Melchizedek perhaps acts as the High Priest of the heavenly Temple, the Priest in the community of gods (angels), as the ruler of the whole world (that is, the head of the sons of the Light) and the antagonist of Melhireshi (the last "Rules over all darkness" and is probably identical with Belial") (Tantlevsky, 2016: 214).

Some Qumran sects could see in Melchizedek the Messiah the Evangelist (cf. Isa.52:7), a Judge who performs some of God's functions in relation to the world on earth. Tantlevsky comes to this conclusion by analyzing the Qumran midrash regarding Melchizedek (ibid, 2016: 215216): "As for the Qumran Midrash Melchizedek, in this work
Melchizedek appears as the head of angels and angellike creatures. He lives in heaven, but at the end of the "tenth" ("last [him]") anniversary ... he will have to appear on earth "in order to atone for (sins) all the sons [of the Light (or: "his generation." - I. T.) and] the people of [her] Rebiya [Melchah] of Zedek" and institute the "judgment of God" over the wicked, Belial and his spirits."

Another version proposed by Tantlevsky on the basis of a translation from the Massoretic text is possible (assuming that Ps. 110 was not written by David, but for him), according to which King David could be Melchizedek (ibid, 2016: 213).

A brief overview of the interpretations regarding Melchizedek provides an opportunity to draw some conclusions. In some works, Melchizedek is presented as a historical person, in others as an eschatological one. Some of those who see not only the historical figure in Melchizedek consider him an angel and even the head of angels, others consider him a type of the priest of the last days, others again consider him a type of the Messiah and the fourth group identifies him with Christ. So who really is Melchizedek?

The purpose of this study is to try to unravel the mystery of the personality of Melchizedek once again. This is important in order, firstly, to more fully and correctly understand the whole Epistle to the Hebrews, secondly, to better understand the essence and ministry of Jesus Christ on the example of Melchizedek, and thirdly, not to distort the Word of God, passing it on to readers and listeners.

Methods of research

In order to analyze the person and identity of Melchizedek, we will conduct a hermeneutic-exegetical study of Heb. 7. It is this method that the author of Hebrews himself uses to reveal the essence of this person.

\section{Results and Discussion}

For the presentation of the exegetical results, it is important to consider the historical context and the structure of the epistle. The letter is mentioned in the message of Clement of Rome to the Corinthians in $95 \mathrm{CE}$. (Gandri, 2001: 415; Gatri, 1996: 514), and therefore it could not be written later than this date. The Epistle of Hebrews repeatedly speaks of the superiority of the priesthood of Christ over the temple system of service, which most likely still took place at the time of writing. This means that the message is most likely written before the destruction of the temple, i.e. until 70 AD.

According by some passages of the Epistle (6:13-20; $10: 32-37 ; 12: 4-11)$, the community to which this message was addressed lived under persecution or was on the threshold of it (Tenni, 361). It is possible that as a result of the persecution, some members of the community had rejected their belief in Christ and had returned to the Jewish system of values (Lawrence, 1991: 860), some took the path of $\sin$ (see $2: 1-4 ; 3-4 ; 5: 11-6: 12 ; 10: 26-31$; 12: 4-17).

This Epistle differs from other Epistles of the New Testament in that it lacks the usual introductory greeting and is held in narrative, almost sermonic style. "The oratorical style and remarks such as "for the time would fail me to tell of" (Heb. 11:32) might seem to indicate a sermon. But the statement, "I have written you briefly" (Heb. 13:22), requires us to acknowledge that Hebrews is a letter after all, written in sermonic style" (Gandri, 2001: 416).

The Epistle is addressed to the Church $(10: 32 ; 13: 7,17)$ and its purpose is to show the excellence of Jesus Christ, to warn members of the community from falling away, and 
possibly to return the apostates to the path of faith. The author is eager to demonstrate the superiority of Christ and his values over Judaism and its system of values. Jesus is higher than angels, higher than prophets. His priesthood is higher than the earthly priesthood. He is the Son of God. The promises for His followers are far more than the promises given to the followers of Moses.

The passage in 7: 1-11 is essentially a hermeneuticexegetical study of Genesis 14: 18-20 and Ps. 110, which the author of the letter, as perceived by many interpreters, carries out on the basis of the Greek text of the Old Testament (Tiselton, 2011: 76). The author uses methods characteristic for the Jewish tradition of his time when conducting the study.

The narrative in Genesis 14 is understood by the author of the epistle not only literally, but also figuratively. This approach to understanding texts was common in Judaism at the time of the emergence of Christianity. The rabbis used both a literal and allegorical interpretation of the text (ibid, 2011: 69-70). "The Jewish scholars of the Talmud interpreted the text based on an understanding of the true (original) meaning of those words that seemed most important in one or another fragment under consideration" (Shulga, 2010: 74).

It is not clear whether the author of Hebrews takes into account the extra-biblical narratives about Melchizedek (Granerød, 2009: 196). "It is possible that there is a connection with the texts of Philo of Alexandria, Josephus Flavius, Qumran manuscripts, Targum Pseudo-Jonathan, 2 Enoch and some rabbinical texts. However, it is likely that these sources do not express their own thoughts and interpretations, but rather reference narrations, widespread at that time, about this ancient king-high priest. Such attention to his image in several Jewish traditions, independent of each other, indicates the important role that Melchizedek played in various religious circles of that time" (Somov, 2009: 11-12).

First, the author of Hebrews exegetically analyzes the text found in Genesis 14:17-20. He pays close attention to the name of Melchizedek (melcise/dek). In the Jewish, and especially biblical tradition, the etymology of the interpretation of names is important (Granerød, 2009: 194), because it carries information about God, man (and about someone else) and speaks of one's essence. Adam, giving names to animals and birds, in one (or several words) gave a description of their essence. Melchizedek is a compound name. It consists of two words: malki - king and cedek - righteousness. Thus, Melchizedek is the king of righteousness.

The second thing that he sees in the account of Melchizedek in Genesis $(14: 18)$ is that he is presented as the king of Salem (basileulv salh $/ \mathrm{m}$ ). The reader of the Bible immediately understands that salh $/ \mathrm{m}$ is probably a locality or city (in comparison with Sodomwn). The author of the epistle interprets "salh/m" (in Hebrew Mls) in the literal (etymological) sense - "peace", relying, perhaps, on the fact that the first biblical mention of Salem (as a city) is found in Ps. 76:2-3, written by Asaph. Probably, this is a city formerly called Jebusite, conquered by David and renamed by him (Josh. 15:8). The second argument for the author of the Epistle of Hebrews, perhaps, is not a parallel between two kings of two cities, but the contradistinction of the king of peace and the king of disorder, noise and turmoil (the word Sodom has this meaning). So Melchizedek is the king of righteousness and the king of peace.

"The etymological interpretation that the Epistle provides for the name of Melchizedek as the "righteous king" is similar to the one found in the texts of Josephus Flavius, Philo of Alexandria and the Targum Pseudo-Jonathan, and interpretation of the "king of peace" is similar to the texts of Philo" (Somov, 2009: 10) and some Qumran texts.

The next aspect that the author of the Epistle of Hebrews sees in the story of Melchizedek is that he is those " to whom also Abraham gave a tenth part of all; first being by interpretation King of righteousness, and after that also King of Salem, which is, King of peace" (7:2). Developing the theme of tithing, the author says: ... Abraham gave tithing to Melchizedek in the person of his descendant Levi (who had not yet been born at that time). And the Levites (descendants of Levi), receiving tithes from the sons of Israel, gave a tenth to God (7:5-10; Num.18:26-29). If Melchizedek has no divine essence, how and why did Abraham give him a t tithe? Nowhere in the Bible does it say that any angel or king will receive tithe as a sign of worship.

The author saw another feature in the personality of Melchizedek. There is nothing in the Bible about his lineage: "a'pa/twr, a'mh/twr, a'genealo/ghtov, mh/te a'rchln h;merw n mh/te zwh v te/lov e\#cwn " (7: 3). Where did the author of the epistle get this information? For a long time exegetes have been struggling with this important issue (Granerød, 2009: 195). Ellingworth (1993: 357) believes that the text in $7: 3$ is taken from some pre-Christian hymn. Somov (2009: 10-11) writes: "The thought in Hebrews 7:3 that Melchizedek had neither a genealogy, nor a date of birth and death, may be based on the method of interpreting Scripture, known as the "argument from silence", which was used by Philo of Alexandria and the rabbis: that which is not in the Scriptures does not exist in the world ... It is quite possible that some extra biblical Jewish traditions, as well as poetic and hymnographic elements, are incorporated into this verse of the Epistle".

However, it is clear that the author of Hebrews does not come to this conclusion using the "argument from silence", but compares Genesis 14 with Psalm 110:4 (like Melchizedek, Christ abides forever; moreover, Hebrews 7: 3 says: not Christ is like Melchizedek, but Melchizedek like the Son of God is forever a priest - me/nei i;ereulv ei'v tol dihneke/v). me/nei (praes. ind. Act.) - to stay, to continue. dihneke/v - continuously, constantly (Cleon, 2001: 811). The thought of the eternal existence of Melchizedek is also evident in 7:8. He has "a testimony of himself that he lives" (e'kei_del marturou/menov o\%ti zh). The parallel with Ps. $110: 4$ is obvious (cf. Num.14:28; Is. 49:18, etc.). One could possibly rather consider the story of Melchizedek in Ps. 110 as coming from an argument from silence. However, we understand that the content of Ps.110 is a revelation of God.

Further, the author draws attention to the blessing that Abraham received from Melchizedek, while showing the superiority of the latter (Heb.7:7). He connects this blessing with the blessing which God had promised to Abraham (Gen.12:1-3). Especially phrases like the following are important to consider: "... I ... bless you" (12:2) and "... and blessed the one who had received the promises. And without all contradiction, the lesser is blessed by the better" (Heb. 7:6-7). Thus, the author claims that God Himself (and not Shem) blessed Abraham and thereby fulfilled His promise.

Another detail in Ps.110:4 is noted by the author of the epistle of Hebrews: the priesthood of Melchizedek is forever (as opposed to the priesthood of the sons of Levi).

All the aforementioned reflections by the Hebrews author clearly indicate parallels in the stories of Christ and Melchizedek. Melchizedek is the king of righteousness and God (Christ) is the king of righteousness. Melchizedek is the king of peace and Christ is the prince of peace (Is. 9:6). Christ is the eternal God (Heb. 1:7-12) and Melchizedek 
has an eternal existence. The priesthood of both Melchizedek and Christ is eternal.

So, are then Melchizedek and Christ one and the same person? Seems to be, yes. However, many researchers are confused by the phrase "without a father, without a mother, without a genealogy." Christ, they believe, has had both a Father and a mother and a family tree (Peeler, 2011: 164). And, therefore, they don't identify Melchizedek with Christ, but considered him only a prototype of Christ. However, such conclusion might be too hasty. In the Bible, we encounter the phenomenon of epiphany. If, as John notes in his Gospel, "No one has ever seen God", then whom did Abraham see (Genesis 18) and whom did Moses see (Exodus 33:11)? They did not see the Father; they saw the Son. "The only begotten Son, who is in the bosom of the Father, he hath declared him" (John 1:18). So, did not the Son of God appear before Abraham? Then, before incarnation, He did not have a mother, He did not have an earthly father, and therefore, it was not a question of His genealogy.

The Midrash text condemns Melchizedek for his haste. Allegedly, he blessed Abraham before he blessed the Creator: "And so two great men met. Shem blessed Abram: "Blessed be Abram by G-d the Most High, Lord of heaven and earth, and blessed be G-d Almighty, who caused your enemies to fall before you!" he exclaimed. "Ashem was going to make Shem the forefather of the koanim, the priests, but since he blessed Abram earlier than his Creator, Ashem took the priesthood from Shem and transferred it to Abram" (Rabbi Moshe Veysman). But, taking into account all of the above, we can say: God in His Son (Melchizedek) accomplished in the life of Abraham what he had promised.

So, comparing Melchizedek and Jesus, it should be concluded: either it is one and the same Person (Shumilin, 1998: 28-29), or there is another person who is additional to the Trinity (ever-living), comparable to Christ.

\section{Conclusion}

Based on the context of the Epistle to the Hebrews, we can say that the author wanted to show the superiority of Christ over the angels, over all earthly authorities (Abraham, Moses, Aaron, etc.) and to demonstrate His divinity (in particular, through the person of Melchizedek). This way he builds an argument in order to encourage retreating Christians to return to faith in Jesus as well as invite those who had not yet turned to Him to devote their lives to Christ.

The author also had a second purpose when discussing the person of Melchizedek. He not only intended to prove Christ's divinity, but also wanted to demonstrate that God the Father acted through Christ in the Old Testament and also continues to do so in the New Testament. Jesus is a faithful High Priest.

\section{REFERENCES}

Somov, A. (2009). Obraz Melkhisedeka v Poslanii k Yevreyam $i \mathrm{v}$ iudeyskikh istochnikakh mezhzavetnogo perioda. St.Petersburg: Yevangelichesko Reformatorskaya Tserkov "Put, Istina i Zhizn". (In Russian)

Rabbi Moshe Veysman. Midrash rasskazyvaet. Retrieved from http://lib.ru/RELIGION/IUDAIZM/WEJSMAN/midr1.txt (In Russian)

Bruce, F. F. (1964). The New International Commentary on the New Testament. The Epistle to the Hebrews. BM. B. Eerdmans Publishing Company. Grand Rapids Michigan.

Tantlevskiy, I. R. (1994). Istoriya i ideologiya kumranskoy obshchiny. St.Petersburg: Tsentr, Peterburgskoe Vostokovedenie. (In Russian)

losif, Flaviy (1900). ludeyskie drevnosti [translate by G. G. Genkel]. St.Petersburg: Book.1, Ch.10:2 Retrieved from http:// www.vehi.net/istoriya/israil/flavii/drevnosti/01.html (In Russian)

Tolkovaya Bibliya ili kommentariy na vse knigi Svyashchennogo Pisaniya Vetkhogo i Novogo Zaveta (1987). Vol.3. (1911 1913). Stokgolm: Izdanie preemnikov Lopukhina A.P. Vtoroe izdanie instituta perevoda Biblii. (In Russian)

Peeler, Amy L. B. (2011). You Are My Son': The Family of God in the Epistle to the Hebrews. PhD dissertation. Princeton, NJ.

Mathews, Joshua G. (2013). Melchizedek's alternative priestly order: a compositional analysis of Genesis 14:18-20 and its echoes throughout the Tanak. Winona Lake, Ind: Eisenbrauns.

loann, Zlatoust. Besedy na poslanie $k$ Yevreyam. Beseda 2. Retrieved from http://www.biblioteka3.ru/biblioteka/zlatoust/ tom_12_1/index.html (In Russian)

Feofilakt, Bolgarskiy. Tolkovanie na poslanie k Yevreyam. Retrieved from http://feofilakt.ru/evreyam/blog (In Russian)

Granerød, Gard. (2009). Melchizedek in Hebrews. Biblica: 188-202.

Sannikov, S. (Chief ed.) (2016). Slavyanskiy Bibleyskiy Kommentariy. Moscow: YeAAA, Bibleyskaya liga, 1834 s. (In Russian) Apokrif Melkhisedek. Biblioteka Nag-Khammadi. Retrieved from http://apokrif.fullweb.ru/nag_hammadi/melhiz.shtml (In Russian)

Kniga Slavyanskogo Yenokha. O zhene Nira. Retrieved from https://knigism.online/secondreader/56109?page $=9$ (In Russian)

Kharchlaa, P. (Chief ed.) (1990). Tolkovanie Novozavetnykh Poslaniy i Knigi Otkroveniya. (transl. from Engl.) Khristianskoe Izdatelstvo, 593 p. (In Russian)

Tantlevskiy, I. R. (2016). Psalom 110[109] kak istochnik religiozno-teologicheskoy kontseptsii kumranskogo "Midrasha Melkhisedeka" (1Q13). Vestnik Russkoy khristianskoy gumanitarnoy akademii. Vol. 17. Issue 4. Retrieved from http://rhga.ru/ upload/iblock/1e1/1e1d6241e1a0e0008beae29c3a4706d4.pdf (In Russian)

Gandri, R. (2001). Obzor Novogo Zaveta. St.Petersbutg: Khristianskoe obshchestvo "Bibliya dlya vsekh", 493 p. (In Russian)

Gatri, D. (1996). Vvedenie v Novyy Zavet. Odessa: Bogomyslie, 800 p. (In Russian)

Tenni, M. K. (1990). Mir Novogo Zaveta. International Correspondence Institute, 428 p. (In Russian)

Lawrence, Richard O. (1991). The Bible Reader's Companion. Victor Books. A Division of Scripture Press Publication Inc. (USA, Canada, England).

Tiselton, E. (2011). Germenevtika (transl from Engl.). Cherkassy: Kollokvium, 430 p. (In Russian)

Shulga, Ye. N. (2010). Ekzegezis: zarozhdenie i razvitie metoda interpretatsii. In: Tsennosti i smysly. Moscow: Avtonomnaya nekommercheskaya obrazovatelnaya organizatsiya Institut effektivnykh tekhnologiy: 71-95. (In Russian)

Ellingworth, P. (1993). New international Greek Testament Commentary. The Epistle to the Hebrews. A Commentary on the Greek Text. William B. Eerdmans Publishing Company. Grand Rapids Michigan. The Paternoster Press Carlisle, $764 \mathrm{p}$.

Kleon, L. (2001). Rodzhers-mladshiy. In: Kleon L. Rodzhers III. Novyy Lingvisticheskiy i ekzegeticheskiy klyuch k grecheskomu tekstu Novogo Zaveta: (Transl. from Engl.) St. Petersburg: Khristianskoe obshchestvo "Bibliya dlya vsekh" (In Russian)

Shumilin, A. (1998). Poslanie k Yevreyam i problema "otpadshikh" v Yevr.6:4-6. Bogomyslie. Almanakh, 7: 8-55 (In Russian)

\section{LIST OF REFERENCES LINKS}

Сомов А. Образ Мельхиседека в Послании к Евреям в иудейских источниках межзаветного периода. Санкт-Петербург: Евангельско-Реформаторская церковь "Путь, Истина и Жизнь", 2009.

Рабби Моше Вейсман. Мидраш рассказывает. URL: http:// lib.ru/RELIGION/IUDAIZM/WEJSMAN/midr1.txt (Дата обращения: 19.02.2019)

Bruce F. F. The New International Commentary on the New Testament. The Epistle to the Hebrews. BM. B. Eerdmans Publishing Company. Grand Rapids Michigan, 1964.

Тантлевский И. Р. История и идеология кумранской об- 
щины. Санкт-Петербург: Центр, Петербургское востоковедение, 1994.

Иосиф Флавий. Иудейские древности ; [пер. Г. Г. Генкель]. Кн.1, Гл.10:2, 1900. URL: http://www.vehi.net/istoriya/israil/ flavii/drevnosti/01.html (Дата обращения: 13.06.2019)

Толковая Библия или комментарии на все книги Священного письма Ветхого и Нового Завета. Т.3. (1911 - 1913). Стокгольм: Издание преемников Лопухина А.П. Второе издание Института перевода Библии, 1987.

Peeler Amy L. B. You Are My Son': The Family of God in the Epistle to the Hebrews. PhD dissertation. Princeton, NJ, 2011.

Mathews Joshua G. Melchizedek's alternative priestly order: a compositional analysis of Genesis 14:18-20 and its echoes throughout the Tanak. Winona Lake, Ind: Eisenbrauns, 2013.

Иоанн Златоуст. Беседы на Послание к Евреям. Беседа 2. URL: http://www.biblioteka3.ru/biblioteka/zlatoust/tom_12_1/ index.html (Дата обращения: 18.06.2019)

Феолифакт Болгарский. Токование на Послание к Евреям. URL: http://feofilakt.ru/evreyam/blog (Дата обращения: 01.07.2019) 202

Granerød Gard. Melchizedek in Hebrews. Biblica, 2009: 188-

Славянский Библейский комментарий / С. Санников (гл. ред.). М.: ЕААА, Библейская Лига, 2016. 1834 с.

Апокриф Мелхиседек. Библиотека Наг-Хаммади. URL: http:/ lapokrif.fullweb.ru/nag_hammadi/melhiz.shtml (Дата обращения: 13.05.2019)

Славянская книга Еноха (Книга тайн Еноха). О жене Нира. URL: https://knigism.online/secondreader/56109?page=9 (Дата обращения: 06.05.2019)

Толкование новозаветных посланий и книги Откровения / П. Харчлаа (гл. ред.). Христианское издательство, 1990. 593 c.
Тантлевский И. Р. Псалом 110[109] как источник религиозно-теологической концепции кумранского "Мидраша Мелхиседека" (11Q13). Вестник РХГА. 2016. Т. 17. Вып 4. URL: http://rhga.ru/upload/iblock/1e1/1e1d6241e1a0e0008beae29c3a4706d4.pdf (Дата обращения: 18.07.2019)

Гандри Р. Обзор Нового Завета. Санкт-Петербург: Христианское общество "Библия для всех", 2001. 493 с.

Гатри Д. Введение в Новый Завет. Одесса: Богомыслие, 1996. $800 \mathrm{c}$.

Тенни М. К. Обзор Нового Завета. Москва: Духовное возрождение, 2000. URL: http://abv.hristianski.net/pluginfile.php/513/ mod resource/content/1/\%D0\%A2\%D0\%B5\%D0\%BD\%D0\%B8_\%D0\%9D\%D0\%97_\%D0\%BE\%D0\%B1\%D0\%B7\%D0\%BE\%D1\%80.pdf (Дата обращения: 18.03.2019)

Lawrence Richard O. The Bible Reader's Companion. Victor Books. A Division of Scripture Press Publication Inc. (USA, Canada, England), 1991

Тисельтон Э. Герменевтика ; [пер. с англ.]. Черкассы: Коллоквиум, 2011. 430 с.

Шульга Е. Н. Экзегезис: зарождение и развитие метода интерпретации. Ценности и смыслы. 2010. №4 (7). URL: https:/ /cyberleninka.ru/article/n/ekzegezis-zarozhdenie-i-razvitiemetoda-interpretatsii (дата обращения: 15.02.2019).

Ellingworth P. New international Greek Testament Commentary. The Epistle to the Hebrews. A Commentary on the Greek Text. William B. Eerdmans Publishing Company. Grand Rapids Michigan. The Paternoster Press Carlisle, 1993. 764 p.

Клеон Л. Роджерс-младший. Клеон Л. Роджер III. Новый лингвистический и экзегетический ключ к греческому тексту Нового Завета; (пер. с англ.) Санкт-Петербург: Христианское общество "Библия для всех", 2001.

Шумилин А. Послание к евреям и проблема "отпавших" в Евр. 6.4-6. Богомыслие. Альманах. 1998. Вып. 7. С. 8-55.

Олександр Шумілін,

Бішкекський Біблейський коледж (м. Кант, Киргизстан)

e-mail: bukyrg59@gmail.com, ORCID 0000-0002-3087-5292

\section{МЕЛХІСЕДЕК ОЧИМА АВТОРА ПОСЛАННЯ ДО ЄВРЕЇВ}

Стаття присвячена вивченню особи Мелхіседека, яка описана в Посланні до Євреїв. Подано огляд існуючих щодо цього біблійного персонажа джерел і тлумачень, показано ̈̈х різноманіття. Зроблено ще одну спробу, слідуючи за автором Послання..., розгадати таємницю цієї особистості. В основу дослідження покладено герменевтико-екзегетичний метод. Показано, як, крок за кроком, автор Послання веде читача до розкриття сутності Мелхіседека, який справляє, безумовно, вагомий вплив на мислення і тодішніх, i сьогоднішніх читачів. На початку дослідження зроблено короткий вступ щодо Послання, описано загальне історичне тло. Автор передбачає і аргументує, що послання в стилі наративу було написане або в період гонінь на християн, або в час, що йому передував. Очевидно, важкі часи вплинули на віру членів громади. Дехто з них збайдужів, дехто відпав, дехто згрішив, а ще хтось, можливо, знов повернувся до іудейської системі цінностей. У Посланні автор намагається знову звернути увагу членів громади на Христа. Він показує Його перевагу над пророками, Ангелами, Авраамом, Мойсеєм, Аароном, старозаповітною священицькою системою служіння. Автор показує божественність Ісуса Христа, говорить про безцільність, безглуздість і навіть загрозу життю без Нього і закликає членів громади повернутися до віри в Нього. У своєму герменевтико-екзегетичному дослідженні старозаповітних оповідань про Мелхіседека в Бут.14: 18-20 і Пс.109: 4 автор Послання використовує традиційні в його час методи інтерпретації рабинами Письма. Він показує, що Мелхіседек $є$ не просто історичною Особистістю, а й есхатологічною. Він не тільки прообраз священика майбутнього, не просто прообраз Месії. Він і є Месія, Син Божий. Особистість Мелхіседека порушена автором Послання не тільки для того, щоб показати Його божественність і тотожність 3 Христом, а й показати, що Бог Батько діяв через Нього в Старому Заповіті, а також продовжує діяти і в Новому Заповіті Ісус -вірний Первосвященик.

Ключові слова: Мелхіседек; Мелхіседек і Христос; Мелхіседек в Посланні до Євреїв; священство Мелхіседека; Первосвященство Христа; Мелхіседек і Авраам.

\section{(C) Shumilin Alexander}

Надійшла до редакції: 27.09.2019

Прийнята до друку: 10.10.2019 